Eckert D., PhD Geography, Professor

CNRS Géocités - Paris - Centre Marc Bloch, Berlin, Germany

\title{
UKRAINIAN BORDER: CURRENT STATE AND PROBLEMS
}

This article analyses Ukraine's current borders, de jure and de facto, from a geopolitical point of view. Significant changes in the border regime occurred after the political events of 2014. The emergence of de facto borders after the annexation of Crimea and the hostilities in eastern Ukraine raise the question not only of the direction of the Ukrainian state's foreign policy, but also has fundamental consequences for domestic policy. The presence of international organisations monitoring parts of the state border shows that Ukraine is involved in the process of combating illegal immigration and smuggling, on the one hand, and that it has not solved all its state building problems, on the other. The delimitation of state borders (demarcation) with the other former Soviet republics has taken a long time for land borders and has not been completed for maritime borders. Today's Ukraine, in the context of European integration, opens its borders to the West and minimizes its contacts with the East. The sharp deterioration in relations with Russia following the annexation of Crimea, Russia's support for separatist entities in eastern Ukraine has led to the abandonment of cross-border cooperation between border regions, including for mechanisms as effective as Euroregions. The need to amend current Ukrainian legislation, to take into account the political and legal status of de facto borders is an important point at the moment. To achieve this objective, it is necessary not only to draw on the experience of the functioning of the State border with Moldova in its section not controlled by the Moldovan government, but also to develop new approaches to facilitate the lives of displaced persons, legalize their legal status and facilitate the crossing of the line of demarcation.

Keywords: geopolitics, Ukraine, state border, separation line, separatism.

Д. Эккерт, канд. геогр. наук, проф.

CNRS Геомиста, Париж, Франция - Центр имени Марка Блока, Берлин, ФРГ

\section{УКРАИНСКИЕ ГРАНИЦЫ: СОВРЕМЕННОЕ СОСТОЯНИЕ И ПРОБЛЕМЫ}

Перевод с фрранцузского языка сделан И.Г. Савчуком

В статье с позиций геополитики анализируются современные государственные границы Украины de јиге и de fасtо. Отмечаются кардинальные изменения в режиме пересечения границы после политических событий 2014 года. Появление границ de fасtо после аннексии Крыма и боевых действий на востоке Украины ставит вопрос не только об изменении внешнеполитического вектора государственной политики, но и о кардинальных изменениях во внутренней политике. Феномен присутствия и контроля над частью соответствующих государственных грании со стороны международных организаций свидетельствует, с одной стороны, о включении Украины в общеевропейские процессы безопасности и координации усилий в сфере борьбы с незаконным перемещением иммигрантов и контрабандой, а с другой - указывает на существование нерешенных проблем в государствостроении. Реальное внедрение на местности (демаркация) государственных границ с бывшими советскими республиками растянулось во времени на суше и так и не перешло в фазу активных переговоров о морских границах. Таким образом, современная Украина в рамках евроинтеграционного курса открывает государственную гранииу на западе и минимизирует контакты на востоке. Резкое ухудшение отношений с Россией после аннексии Крыма и поддержки сепаратистских образований на востоке Украины привело к свертыванию трансграничного сотрудничества приграничных регионов, в т.ч. в рамках такого эффективного механизма, как еврорегионы. Необходимость внесения изменений в действующее законодательство Украины относительно политико-правового статуса границ de fасtо является важным вопросам современного развития. Для этого необходимо не только привлечь опыт внедрения соответствующих правовых механизмов, которые реализованы под эгидой EC относительно режима государственной границы с Молдовой на тех его участках, не контролируемых Правительством этой страны, но и разработать новые меры, которые бы способствовали устройству вынужденных переселенцев и нормализовали их правовой статус и режим пересечения линии разграничения.

Ключевые слова: геополитика, Украина, государственную границу, линия разграничения, сепаратизм.

http://doi.org/10.17721/1728-2721.2019.75.5

УДК 911.3

О. Кононенко, канд. екон. наук, доц., В. Молодика, магістр Київський національний університет імені Тараса Шевченка, Київ, Україна

\section{ТИПІЗАЦІЯ РЕГІОНІВ УКРАЇНИ ЗА МОЖЛИВОСТЯМИ СТАЛОГО УПРАВЛІННЯ ВІДХОДАМИ}

Стале управління відходами є актуальним завданням як для сучасної науки, так і для управлінської практики. Пошук ефективних механізмів управління в рамках даного дослідження здійснено відповідно до концепції сталого розвитку та циркулярної економіки. Перехід до моделі сталого управління відходами розглядається як поступальний процес зростання частки відходів виробництва та споживання, що повертаються до виробничого циклу. У зв'язку з цим, оцінка сталого управління відходів в регіонах має включати індикатори динаміки щодо основних складових управління відходами. Методика даного дослідження ґрунтується на узагальненні показників сталого поводження з відходами, що були проаналізовані станом на певний момент часу, а також у динаміці. Було проведено групування регіонів країни за ефективністю управління відходами. Виділені чотири групи регіонів мають чітко виражену територіальну прив'язку, спільні риси щодо виробничого профілю та структури утворених відходів. Типізація регіонів України розроблена на основі групування, а також з урахуванням спеціалізації регіонів у загальнонаціональному поділі праці, рівнів урбанізації регіонів. Було виділено п'ять типів регіонів: два типи з високою часткою побутових відходів, регіони з переважанням промислових відходів, та два типи індустріально-аграрних регіонів, що мають змішану структуру відходів, з суттєвою часткою відходів сільського господарства. Для регіонів одного типу, як правило, характерним є схожість проблем щодо поводження з відходами. Це можуть бути як традиційні проблеми накопичення великої кількості відходів у місцях їх зберіеання та захоронення, так і нові виклики, пов'язані з міграцією населення, утворенням нових адміністративних одиниць (об'єднаних територіальних громад), що вносять зміни в функціонування діючої системи поводження з відходами. Суттєві відмінності щодо основних показників поводження з відходами для різних типів вимагають використання подібних (типових) підходів до розроблення регіональних стратегій та регіональних планів управління відходами.

Ключові слова: відходи, сталий розвиток, циркулярна економіка, ефективність управління відходами, типізація.

Постановка проблеми. Управління відходами розглядається в різних контекстах: як одна з гострих екологічних проблем, напрям державної екологічної політики, складова сталого розвитку, вид економічної діяльності. Увага до даної проблеми пов'язана з існуванням об'єктивних перешкод на шляху ефективного поводження з відходами в країнах з перехідною економікою, у тому числі посткомуністичних країнах. Управління відходами відноситься до зростаючих секторів економіки, що має на меті досягнення не стільки економічних, як екологічних і соціальних цілей. Цим обумовлюється необхідність розроблення спеціального підходу щодо регулювання всього процесу поводження з відходами, а також застосування 
механізмів стимулювання інвестицій та оцінки ефективності системи управління відходами

У представленому дослідженні аналіз управління відходами проводиться з позицій, визначених у документах $\mathrm{OOH}$ та ЄС щодо сталого розвитку, зеленої економіки та циркулярної економіки [16], [9]. Ефективність управління відходами має оцінюватись з урахуванням усіх позитивних і негативних ефектів діяльності, що пов'язані з утворенням, переробкою, утилізацією та видаленням відходів. Відповідно до вимірів сталого розвитку, індикатори сталого поводження з відходами було об'єднано в три групи: економічні, соціальні та екологічні. Визначений перелік показників може лягти в основу оцінки ефективності управління відходами на шляху виконання Цілей сталого розвитку, а також євроінтеграції України, потреба в чому виникає вже зараз [3].

Теоретичні основи сталого управління відходами в perioнах. Перехід до моделі сталого управління відходами базується на ідеях сталого розвитку та циркулярної економіки. Відповідно до теоретичних основ циркулярної економіки [17] відходи розглядаються як ресурс розвитку, що має певні корисні властивості. Вони є частиною матеріальних потоків в економіці так само, як органічні відходи $€$ частиною біологічних циклів природних систем. Для того, щоб більша частина відходів була залучена до матеріальних ресурсів, необхідно враховувати їх вартість на всіх етапах використання ресурсу: від видобутку до його утилізації та повторного використання [6]. Базовими принципами циркулярної економіки залишаються 3R принципи (reduce, reuse and recycle) та дотримання ієрархії відходів при побудові системи управління відходами країни чи регіону. Використання економічних важелів, а також окремих адміністративних методів впливу має сприяти розвитку управління відходами як ефективної та конкурентоспроможної галузі економіки [12]

У системі управління відходами на макрорівні (рівень країни або регіону) взаємодіють різні суб'єкти, що мають свої інтереси й цілі. Це центральний уряд, органи місцевого управління та самоврядування, підприємства, громади та неурядові організації, окремі громадяни. Ïх ефрективна взаємодія має сприяти прогресу на шляху зростання частки відходів, що повертаються у виробничий процес, а також зменшенню утворення відходів загалом. Основні завдання Уряду у сфрері поводження з відходами полягають у формуванні збалансованої системи, що буде відповідати інтересам основних стейхолдерів та забезпечить при цьому перехід до моделі сталого управління відходами. Для того, щоб управління відходами відповідало вимогам сталого розвитку, воно має бути екологічно ефективним, економічно доцільним та соціально прийнятним [14]. Це визначає важливість зв'язків між основними стейкхолдерами, які включають не тільки традиційні контроль і нагляд, але й координацію та узгодження основних заходів щодо управління відходами.

У межах певної місцевості (регіон, населений пункт) $€$ можливості для більш тісної взаємодії між основними учасниками процесу управління відходами. Розуміння населенням і місцевим бізнесом гостроти цієї проблеми $\epsilon$ умовою ефективної політики в цій сфрері. Регіони можуть мати різний рівень ефективності управління відходами внаслідок природних передумов, економічних, соціальних, історичних особливостей розвитку. Можна говорити про специфіку поводження з відходами в індустріальних, аграрних, рекреаційних регіонах [11], [8], [13]. Наприклад, рекреаційні регіони характеризуються сезонністю утворення відходів, що необхідно враховувати при розвитку інфраструктури, будівництві потужностей 3 переробки твердих побутових відходів.

Оцінювання ефективності управління відходами має доповнювати моніторинг прогресу на шляху сталого розвитку, стати основою для коригування управлінського про- цесу, а також розроблення Національної стратегії поводження з відходами та відповідних регіональних планів. Достатній обсяг інформації щодо стану й динаміки управління відходами є каталізатором й умовою необхідних змін.

Метою статті $€$ загальна характеристика управління відходами в Україні, а також виявлення регіональних особливостей, що обумовлюються розміщенням промисловості, підприємств енергетичного сектору, розселенням населення та іншими чинниками. Україна рухається в напрямі сталого управління відходами шляхом, що вже пройшли більшість пострадянських країн. Для України важливо проводити реформування цієї сфери відповідно до вимог Директиви ЄС 2008/98/EC та інших документів, а також враховувати досвід європейських країн.

Методика оцінки ефективності управління відходами в регіонах. На глобальному й національному рівнях перелік показників щодо управління відходами є достатньо широким. Відповідно до Цілей сталого розвитку стан сфери поводження з відходами характеризується через показники утворення небезпечних відходів на душу населення, частки перероблюваних небезпечних відходів за видами обробки, також враховується національний рівень переробки відходів [10]. Ці індикатори були адаптовані для України, i, відповідно, національні Цілі сталого розвитку включають наступні індикатори: обсяг утворених відходів від усіх видів діяльності на одиницю ВВП, частка перероблених та утилізованих відходів у загальному обсязі та питома вага перероблених відходів, накопичених у місцях видалення, у загальному обсязі накопичених відходів [5]. 3 метою проведення регіональних порівнянь кількість первинних індикаторів було розширено за рахунок кількості утворених відходів I-IV класів небезпеки на км² площі регіону, частки спалених й утилізованих відходів у загальному обсязі утворених відходів, кількості суб'єктів підприємницької діяльності, які здійснюють діяльність у сфері поводження з небезпечними відходами на території регіону [18]

У свою чергу, Євростат спирається на показники утворення відходів на душу населення (з виділенням двох категорій: безпечних та небезпечних), часток відходів, що переробляються та часток відходів, що використовується як сировина для виробництва [15]. Фактично ці ж показники беруться за основу при аналізі сфрери поводження 3 відходами і Європейським Агентством 3 навколишнього середовища. При цьому слід зазначити, що система показників залишається неповною. Наприклад, тільки декілька країн ЄС збирають статистичну інформацію, що характеризує повторне використання товарів у побуті [19].

Порівняльний аналіз методичних підходів до оцінки ефективності функціонування циркулярної економіки представлено в роботі Д. Банайте і Р. Тамашюнене [7]. Базові індикатори щодо поводження з відходами згруповані за ознаками відповідності:

- принципам циркулярної економіки (що характеризують зменшення утворення, переробку та повторне використання відходів);

- компонентам сталого розвитку (соціальні, економічні, екологічні);

- рівням оцінки (рівень підприємств - макрорівень; рівень груп підприємств, галузей - мезорівень; рівень міст, регіонів, районів, країн - макрорівень).

У рамках цього дослідження було здійснено спробу порівняльної оцінки сталого управління відходами в регіонах України з погляду прогресу по основних складових сталого розвитку. Ключовими вихідними вимогами до оцінки були: 1) відповідність субіндексів основним компонентам сталого розвитку (соціальному, екологічному, економічному); 2) можливість аналізу не лише стану управління відходами в певний момент часу, але й у динаміці; 3) включення до переліку показників, що ілюструють управління відходами на різних етапах життєвого циклу 
товару; 4) виділення типів регіонів за особливостями розвитку сфери поводження з відходами. Отже, перелік вихідних показників має наступний вигляд:

1. Загальна кількість утворених відходів на одиницю ВРП, кг/тис.грн. (А1);

2. Кількість утворених побутових відходів на 1 ос., кг/ос. (A2);

3. Частка площі регіону під сміттєзвалищами, \% (А3);

4. Частка виробленої продукції у сфрері поводження з твердими побутовими відходами до загального обсягу виробленої продукції в регіоні, \%о(В1);

5. Частка зайнятих у сфері поводження з відходами у загальній кількості зайнятого населення, \%о (B2);

6. Частка площ несанкціонованих сміттєзвалищ у загальній площі сміттєзвалищ, \% (В3);

7. Частка перероблених (утилізованих) відходів, \% (C1);

8. Частка населення, охопленого послугами збирання ТПВ, \% (С2);

9. Частка відходів, що захороняються, \% (С3).

Більшість індикаторів характеризують ефективність управління відходами, оскільки є відносними та відповідають європейській системі моніторингу поводження з відходами й можуть використовуватись для міждержавних порівнянь. Водночас, у переліку немає показників щодо повторного використання відходів через відсутність відповідної статистики для регіонів України. Натомість проаналізовано доступні показники діяльності сфери поводження $з$ відходами, зростання якої $є$ критерієм ефективності функціонування механізмів сталого поводження з відходами та сорормованості нормативно-правової бази.

у представленому дослідженні матриця показників була використана для виявлення: 1) регіональних особливостей управління відходами в Україні станом на 2016 рік; 2) прогресу України в цілому та окремих її регіонів на шляху запровадження більш ефективного управління відходами.

Регіональні диспропориії розвитку ссери поводження з відходами були оцінені на основі $\bar{K}_{l}$ - інтегрального індексу ефективності управління відходами для регіону $i$. Він був розрахований як середнє арифметичне трьох субіндексів ефективності управління відходами (відповідно $\overline{K 1_{l}}$ - субіндекс економічної ефективності управління відходами; $\overline{K 2_{\imath}}$ - субіндекс соціальної ефективності управління відходами і $\overline{K 3_{l}}-$ екологічної). Відповідно кожен зі згаданих вище субіндексів був також обрахований як середньоарифметичне трьох нормованих показників, що представляють відповідний блок. Метод нормування, а також розрахунку інтегрального індексу та субіндексів на прикладі показника А1 наведено нижче:

$$
\begin{gathered}
\overline{K_{l}}=\left(\overline{K 1_{l}}+\overline{K 2_{\imath}}+\overline{K 3_{\imath}}\right) / 3 \\
\overline{K 1_{\imath}}=\left(K A 1_{i}^{6}+K B 1_{i}^{6}+K C 1_{i}^{6}\right) / 3 \\
K A 1_{i}^{6}=\frac{A 1_{\max }^{6}-A 1_{i}^{6}}{A 1_{\text {max }}^{6}-A 1_{\text {min }}^{6}} \\
K A 1_{i}^{6}=\frac{A 1_{i}^{6}-A 1_{\text {min }}^{6}}{A 1_{\text {max }}^{6}-A 1_{\text {min }}^{6}}
\end{gathered}
$$

$K A 1_{i}^{6}$ - нормоване значення показника $\mathrm{A} 1$ для регіону $i$ за 2016 рік; $A 1_{\text {max }}^{6}$ - максимальне значення показника A1 серед регіонів України за 2016 рік; $A 1_{i}^{6}$ - значення показника А1 для регіону $i$ за 2016 рік; $A 1_{\text {min }}^{6}$ - мінімальне значення показника А1 серед регіонів України за 2016 рік. Формула 3 використовується для показниківстимуляторів, а формула 4 - для дестимуляторів.

Прогрес/регрес регіонів України щодо управління відходами був оцінений шляхом порівняння показників за 2013 та 2016 роки. За компонентами сталого розвитку та загалом по всіх 9 показниках було обраховано темпи зростання/спадання ефективності управління відходами. Отже, середній темп зростання/спадання ефективності управління відходами у регіоні $i\left(\bar{D}_{l}\right)$ був обрахований як середнє арифметичне темпів зростанняІспадання економічної, соціальної, екологічної ефективності управління відходами в регіоні $i$ (відповідно коефіцієнти $\overline{D 1_{l}}, \overline{D 2_{l}}, \overline{D 3_{l}}$ ). Кожен $з$ трьох перелічених коефіцієнтів $€$ середнім арифрметичним темпів приросту вихідних показників. Формули обрахунку на прикладі показника А1 наведені нижче.

$$
\begin{gathered}
\overline{D_{l}}=\overline{\left(D 1_{l}\right.}+\overline{D 2_{1}}+\overline{\left.D 3_{l}\right)} / 3 \\
\overline{D 1_{l}}=\overline{\left(D A 1_{i}+D B 1_{i}+D C 1_{i}\right) / 3} \\
D A 1_{i}=\frac{A 1_{i}^{6}-A 1_{i}^{3}}{A 1_{i}^{3}} \\
D A 1_{i}=\frac{A 1_{i}^{3}-A 1_{i}^{6}}{A 1_{i}^{3}}
\end{gathered}
$$

де $D A 1_{i}$ - темп приросту показника $\mathrm{A} 1$ для регіону $i$ за період 2013-2016 рр.; $A 1_{i}^{6}$ та $A 1_{i}^{3}$ - значення показника А1 для регіону $i$ за 2016 та 2013 роки відповідно. Формула 7 використовується для показників-стимуляторів, а формула 8 - для дестимуляторів.

На основі обрахованих індексів та темпів зростання/спадання ефективності управління відходами було побудовано точкову діаграму, що дозволила провести групування регіонів України. Детальна характеристика виділених груп була побудована на аналізі 9 показників, що лягли в основу цієї методики, а також з урахуванням розміщення регіонів, їх спеціалізації в загальноукраїнському поділі праці, рівня урбанізації та інших чинників соціально-економічного розвитку.

Регіональні відмінності управління відходами. Основною рисою сфери поводження з відходами в Україні $є$ суттєві регіональні диспропорції в утворенні відходів. Так, станом на 2017 рік у Дніпропетровській області було утворено в 2437 разів більше відходів, ніж у Закарпатській. Загалом на 4 регіони, у яких найбільше розвинена видобувна промисловість (Дніпропетровську, Луганську, Донецьку та Кіровоградську області), припадає 92 \% усіх утворених відходів. Ми в цьому дослідженні виходимо з того, що на загальний обсяг і структуру утворення відходів у регіоні суттєво впливає його спеціалізація в загальнонаціональному й світовому поділі праці. Тому регіональний план поводження з відходами має враховувати виробничий профріль регіону.

Представлені в табл. 1 індекси та темпи зростання/спадання ефективності управління відходами можуть бути візуалізовані за допомогою точкової діаграми (рис. 1). Загалом більшість регіонів України сформували кластер, для якого характерною $є$ слабка динаміка показників $(-0,2<\bar{D}<0,1)$ та значення індексу ефективності управління відходами нижче середнього $(0,36<\bar{K}<0,47)$. Водночас показники ряду регіонів суттєво відрізняються від середньоукраїнських значень, що дало підстави для проведення групування.

Так, найбільш ефективними регіонами виявилися Чернівецька, Харківська, Закарпатська, Тернопільська, Волинська, Івано-Франківська, Рівненська та Львівська області, які об'єднані у групу 1. Для цієї групи характерний вищий середнього по Україні рівень ефективності управління відходами, а динаміка аналізованих показників залишалась позитивною або з помірними від'ємними значеннями. Частина регіонів у цій групі - регіони Західної України з низькими обсягами утворення відходів (Закарпатська, Львівська, Чернівецька, Рівненська, Волинська, Тернопільська області). Характерною їх ознакою $€$ низька частка промислових відходів, а також загалом високі відносні показники ефективності управління відходами. Щодо Івано-Франківської, Харківської, Запорізької областей, то ці промислові та промисловоаграрні регіони України характеризуються середніми обсягами утворення відходів та вищою за середню ефективність управління відходами. 
До групи ж номер 2 потрапили наступні регіони: Полтавська, Черкаська, Хмельницька, Миколаївська, Сумська, Чернігівська та Вінницька області. Група характеризується доволі високими значеннями загальної рейтингової оцінки сталого поводження з відходами, але внаслідок того, що перелічені регіони мають негативну динаміку в цій сфрері, це ставить групу в зону ризику, оскільки внаслідок від'ємної динаміки регіони можуть відносно швидко опинитися в ролі найменш ефективних у сфрері поводження з відходами.

Група регіонів номер 3 включає Дніпропетровську, Одеську, Кіровоградську, Донецьку, Херсонську та Луганську області. Група, маючи доволі низькі рейтингові оцінки, компенсує це позитивною або близькою до нульової динамікою. Це переважно індустріальні регіони, де розміщено основні матеріаломісткі виробництва країни, а саме шахти, кар'єри, металургійні комбінати, хімічні підприємства, теплові станції тощо. Низький рівень ефективності управляння відходами пов'язаний також з низькою часткою відходів виробництва, що йдуть на переробку через застарілість технологій. Військові дії та окупація частини території зумовили зупинку підприємств. Це стало однією з причин позитивної динаміки значень показників Луганської та Донецької областей. Одеська область увійшла до цієї групи внаслідок високих показників утворення побутових відходів на одну особу, що пов'язано з її рекреаційною спеціалізацією.

Таблиця 1. Індекси та темпи зростання/спадання ефективності управління відходами

\begin{tabular}{|c|c|c|c|c|c|c|c|c|c|}
\hline & Perion & $\overline{\mathbf{K}}$ & $\overline{\mathbf{K 1}}$ & $\overline{\mathrm{K} 2}$ & $\overline{\mathbf{K} 3}$ & $\overline{\mathbf{D}}$ & $\overline{\mathbf{D 1}}$ & $\overline{\mathbf{D 2}}$ & $\overline{\mathbf{D 3}}$ \\
\hline $\mathrm{BiH}$ & Вінницька & 0,458 & 0,512 & 0,455 & 0,407 & $-0,212$ & 0,028 & $-0,111$ & $-0,552$ \\
\hline Вол & Волинська & 0,445 & 0,527 & 0,694 & 0,115 & $-0,034$ & $-0,046$ & $-0,267$ & 0,210 \\
\hline Дн & Дніпропетровська & 0,601 & 0,787 & 0,699 & 0,317 & $-0,138$ & $-0,237$ & $-0,148$ & $-0,027$ \\
\hline Дон & Донецька & 0,462 & 0,572 & 0,537 & 0,275 & $-0,002$ & $-0,287$ & 0,051 & 0,231 \\
\hline Жт & Житомирська & 0,510 & 0,514 & 0,690 & 0,326 & $-0,212$ & $-0,309$ & $-0,317$ & $-0,011$ \\
\hline $3 \kappa$ & Закарпатська & 0,319 & 0,335 & 0,550 & 0,072 & $-0,155$ & $-0,221$ & $-0,663$ & 0,419 \\
\hline $3 \pi$ & Запорізька & 0,388 & 0,267 & 0,591 & 0,306 & 0,027 & 0,201 & $-0,095$ & $-0,025$ \\
\hline IB- $\Phi$ & Івано-Франківська & 0,365 & 0,369 & 0,481 & 0,246 & $-0,009$ & $-0,053$ & $-0,054$ & 0,078 \\
\hline К.обл. & Київська & 0,512 & 0,655 & 0,469 & 0,412 & $-0,311$ & $-0,571$ & $-0,357$ & $-0,005$ \\
\hline Kp & Кіровоградська & 0,578 & 0,851 & 0,731 & 0,153 & $-0,090$ & $-0,552$ & $-0,070$ & 0,353 \\
\hline Лг & Луганська & 0,565 & 0,695 & 0,666 & 0,333 & 0,198 & 0,374 & 0,000 & 0,220 \\
\hline Льв & Львівська & 0,388 & 0,483 & 0,461 & 0,220 & 0,184 & 0,219 & $-0,136$ & 0,470 \\
\hline Мк & Миколаївська & 0,444 & 0,627 & 0,546 & 0,157 & $-0,322$ & $-0,470$ & $-0,277$ & $-0,220$ \\
\hline Одес & Одеська & 0,525 & 0,594 & 0,750 & 0,232 & $-0,144$ & 0,041 & $-0,275$ & $-0,198$ \\
\hline Пт & Полтавська & 0,433 & 0,303 & 0,601 & 0,396 & $-0,179$ & $-0,344$ & $-0,025$ & $-0,167$ \\
\hline $\mathrm{PB}_{\mathrm{B}}$ & Рівненська & 0,420 & 0,318 & 0,596 & 0,346 & 0,096 & 0,224 & $-0,242$ & 0,307 \\
\hline Cy & Сумська & 0,410 & 0,332 & 0,684 & 0,215 & $-0,313$ & $-0,252$ & $-0,592$ & $-0,095$ \\
\hline $\mathrm{Tp}$ & Тернопільська & 0,418 & 0,444 & 0,454 & 0,357 & $-0,040$ & $-0,074$ & $-0,088$ & 0,042 \\
\hline$X p$ & Харківська & 0,430 & 0,413 & 0,645 & 0,231 & $-0,112$ & $-0,176$ & $-0,348$ & 0,186 \\
\hline Xpc & Херсонська & 0,467 & 0,590 & 0,510 & 0,301 & 0,057 & $-0,173$ & $-0,132$ & 0,477 \\
\hline XM & Хмельницька & 0,442 & 0,369 & 0,595 & 0,363 & $-0,382$ & $-0,317$ & $-0,127$ & $-0,703$ \\
\hline $4 \kappa$ & Черкаська & 0,423 & 0,297 & 0,682 & 0,290 & $-0,431$ & $-0,203$ & $-0,976$ & $-0,114$ \\
\hline Чн & Чернівецька & 0,385 & 0,290 & 0,575 & 0,290 & $-0,240$ & $-0,244$ & $-0,424$ & $-0,051$ \\
\hline $4 p$ & Чернігівська & 0,407 & 0,495 & 0,500 & 0,224 & $-0,160$ & $-0,468$ & $-0,133$ & 0,122 \\
\hline \multirow[t]{2}{*}{ Київ } & м.Київ & 0,608 & 0,651 & 0,569 & 0,603 & $-0,284$ & $-0,157$ & $-0,925$ & 0,229 \\
\hline & Україна & 0,456 & 0,492 & 0,589 & 0,287 & $-0,166$ & $-0,163$ & $-0,269$ & 0,047 \\
\hline
\end{tabular}

${ }^{1}$ Примітка. Розраховано авторами за даними Державної служби статистики [1, с. 107-148] та Міністерства розвитку громад і територій України [4].

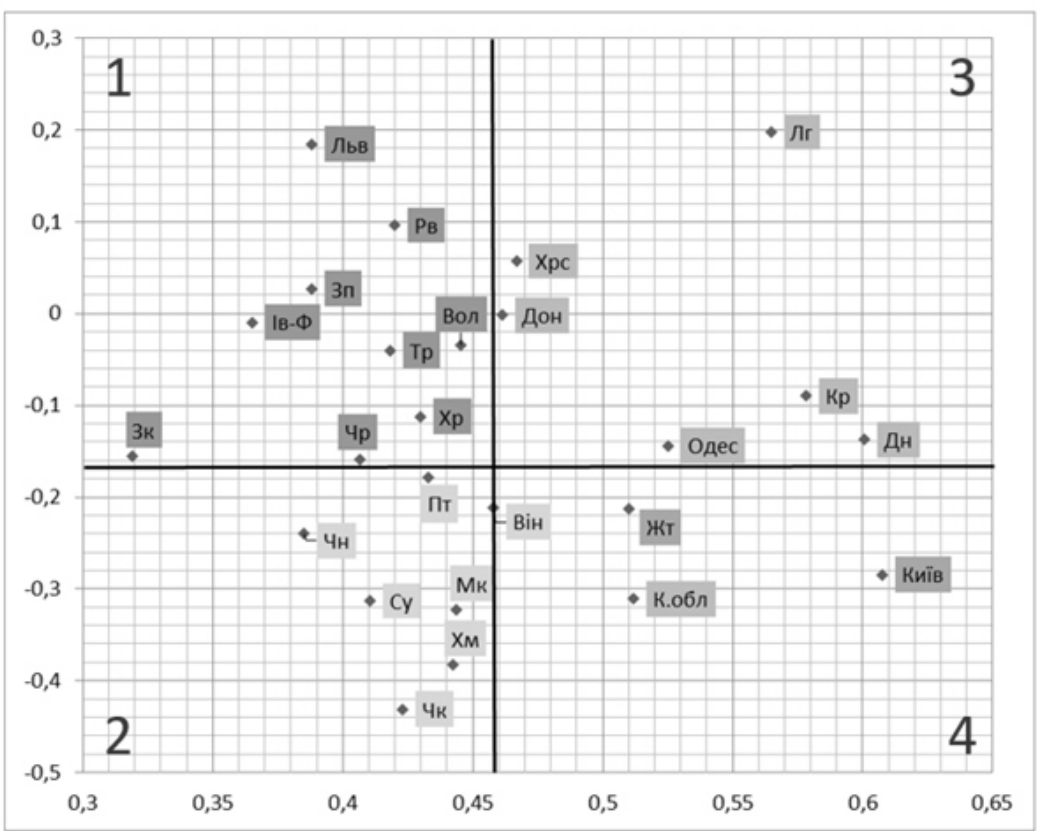

Рис 1. Групування регіонів України на основі значень інтегрального індексу ефективності управління відходами $(\bar{K}$, абсциса) та середнього темпу зростання/спадання ефективності управління відходами $(\bar{D}$, ордината) 
До групи ж номер 4 відносяться Житомирська та Київська області, а також місто Київ. Ця група регіонів характеризується насамперед негативною динамікою сталого поводження з відходами за період 2013-2016 років, а також одними з найнижчих рейтингових оцінок серед усіх регіонів України. Така ситуація тісно пов'язана із збільшенням антропогенного навантаження на Столичний регіон України, до якого входять саме ці адміністративні одиниці. Тобто, внаслідок збільшення кількості населення та економічного зростання в цих регіонах збільшилися обсяги відходів, але застаріла інфраструктура не витримує цих умов, тому відчувається дефіцит робітників, зайнятих у сфері поводження з відходами, не вистачає сміттєзвалищ, а обсяг відходів у розрахунку на одну особу значно зріс, що є негативним фрактором.

Загалом, на основі наведеного вище групування, аналізу первинної статистичної інформації, а також розрахованих показників, нами було виділено типи регіонів, що мають схожі проблеми щодо управління відходами та можливості переходу на модель сталого управління відходами. Крім того, ці регіони мають певну географічну прив'язку та подібну виробничу спеціалізацію.

Тип 1. Високоурбанізовані регіони з високою часткою побутових відходів. До цієї групи відносяться Київ та Київська область. Унаслідок того, що Столичний регіон має значний міграційний приріст населення, кількість утворених побутових відходів $є$ однією з найвищих в Україні (605 кг/ос. в місті Києві та 617 кг/ос. в Київській області). Регіони потребують розбудови сучасної інфраструктури зі збирання та перероблення цього виду відходів. Слід сказати, що Харківська область відповідно до досліджень [2, с. 17-23] є регіоном на постіндустріальній стадії розвитку й за більшістю показників (частка побутових відходів, частка відходів I-III класу небезпеки) може також бути віднесена до цього типу, хоча зараз вона й не має такої кількості проблем у сфері поводження з побутовими відходами, як Столичний регіон.

Тип 2. Регіони з переважанням побутових відходів у загальній структурі та сезонністю їх утворення. До цього типу відносяться Закарпатська, Одеська, Львівська, Миколаївська, Херсонська, Волинська, Івано-Франківська області, в економіці яких значну частку займає рекреаційна діяльність і туризм. Управління відходами в рекреаційних регіонах вимагає гнучкості системи збору й перероблення відходів, особливо в південних регіонах, де $\epsilon$ сезонність у перебуванні туристів. Більшість регіонів цього типу мають середній і високий рівень ефективності управління відходами й лише Одеська область характеризується різким збільшенням утворення відходів останніми роками та невирішеністю проблеми їх збирання та утилізації. Так, в Одеській області тільки 63 \% населення охоплені послугами зі збирання відходів, що нижче за середьоукраїнський рівень.

Тип 3. Регіони з переважанням промислових відходів у загальній структурі та високими обсягами їх утворення. Регіони цієї групи можуть бути охарактеризовані як старопромислові: Дніпропетровська, Кіровоградська, Донецька та Луганська області. Для цієї групи регіонів проблема управління відходами має бути відображена у всіх стратегічних документах, оскільки в регіонах накопичено велику кількість промислових відходів, у тому числі небезпечних. Цей тип об'єднує високоурбанізовані регіони й система управління побутовими відходами потребує вдосконалення, хоча деіндустріалізація й міграційний відтік населення останнім часом обумовили позитивну динаміку ефективності управління відходами.

Тип 4. Індустріально-аграрні регіони зі значними обсягами утворення відходів (Запорізька, Полтавська, Харківська, Сумська, Черкаська області). Регіони, що входять до цієї групи, є промислово розвиненими, але ступінь гостроти проблем поводження 3 відходами $€$ дещо нижчим порівняно з типом 3. Аграрний сектор є достатньо розвиненим у цих областях степової та лісостепової зони й це знаходить відображення в значній частці відходів IV класу небезпеки. Управління відходами має здійснюватись на основі комплексного підходу з урахуванням потреб промислового, аграрного секторів, а також комунальної сфери.

Тип 5. Індустріально-аграрні регіони з низькими обсягами утворення відходів. До цього типу віднесено Вінницьку, Житомирську, Рівненську, Тернопільську, Хмельницьку, Чернівецьку, Чернігівську області. Це найменш проблемі регіони з погляду управління відходами, що розташовані переважно в центральній та західній частинах України. Області $€$ слаборозвиненими, що відображається як у низькому обсязі утворення відходів у цілому, так і низькій частці відходів від економічної діяльності. Більша частина областей має високу порівняно з середньоукраїнськими показниками частку сільського населення, що є загрозою для ефективного управління відходами. У сільській місцевості не сформована система збору, сортування, перероблення та захоронення побутових відходів, також навколо сіл фрормуються стихійні звалища. Тому при розробленні програм поводження 3 відходами слід ураховувати особливості системи розселення, брати до уваги відходи сільського господарства та найбільших промислових підприємств.

Висновки. Управління відходами в Україні не $є$ економічно та екологічно ефективним, що виявляється у високих показниках утворення відходів, низьких обсягах та глибині їх перероблення. Україна потребує глибинного реформування даної сфери, що включає сучасну нормативно-правову базу, економічні механізми стимулювання інвестицій у види діяльності, пов'язані зі збиранням та переробкою промислових, сільськогосподарських та побутових відходів.

Регіональні диспропорції щодо утворення відходів, а також обсягів відходів, що акумульовані за попередні роки, $є$ дуже значними. Кожен регіон, відповідно до свого виробничого профрілю, характеризуються певною унікальністю структури відходів, наявністю сезонної складової, наявними можливостями для їх утилізації. Зібрана первинна інфоомація (9 показників, що характеризують три ключових компоненти сталого розвитку) була опрацьована таким чином, що було виділено 4 групи регіонів за ефективністю управління відходами та динамікою такої ефективності. Найбільш загрозлива ситуація щодо поводження з відходами склалась у Столичному регіоні, а також на сході України, де військові дії стали чинником загострення ряду екологічних проблем, в тому числі i щодо управління відходами.

Авторами запропоновано типологію за переважаючим напрямом управління відходами. Регіони, що віднесені до певного типу, мають схожі проблеми зі збиранням і переробкою відходів, а також схожу структуру відходів. Виробнича спеціалізація регіонів стала суттєвим чинником формування типів регіонів. Також на формування ефективної моделі управління відходами впливає рівень урбанізації областей: як у містах, так і сільській місцевості проблема управління відходами $€$ гострою, але механізм вирішення дещо відрізняється.

Дана типологія може бути використана при розробленні регіональних планів управління відходами, а також вдосконалення державної політики у даній сфері. Подальші розвідки передбачають моніторинг прогресу регіонів щодо сталого управління відходами в цілому, а також 
за співвідношенням основних компонентів сталого розвитку: екологічного і економічного, екологічного і соціального, економічного та соціального.

\section{Список використаних джерел:}

1. Довкілля України за 2017 рік. Статистичний збірник. - К.: Державна служба статистики України, 2018 - 225 с

2. Мезенцев К.В., Підгрушний Г.П., Мезенцева Н.І. Регіональний розвиток в Україні: суспільно-просторова нерівність і поляризація: Монографія. - К.: ДП "Прінт Сервіс", 2014. - 132 с.

3. Моніторинг озеленення економіки при реалізації угоди про асоціацію Україна - ЄС. Аналітична доповідь. - // Електронний ресурс. Режим доступу: https://www.civic-synergy.org.ua/wp-content/uploads/2018/04/ Monitoryng-ozelenennya-ekonomiky-pry-realizatsiyi-Ugody-pro-asotsiatsiyuUkrayina-YES.pdf

4. Стан сфери поводження з побутовими відходами в Україні за 2016 та 2013 роки. Міністерство розвитку громад та територій України // Електронний ресурс. - Режим доступу: http://www.minregion.gov.ua/ napryamki-diyalnosti/zhkh/terretory/stan-sferi-povodzhennya-z-pobutovimividhodami-v-ukrayini-za-2016-rik/

5. Стратегія сталого розвитку України до 2030 року. Проект 2017 // Електронний ресурс. - Режим доступу: http://www.ua.undp.org/content/ ukraine/uk/home/library/sustainable-development-report/Sustainable-DevStrategy-for-Ukraine-by-2030.html

6. Andersen M.S. An introductory note on the environmental economics of the circular economy // Sustainability Science - 2007. - № 2, P. 133-140.

7. Banaitè, D. Tamošiūnienè, $R$. Sustainable development: the circular economy indicators' selection model // Journal of Security and Sustainability Issues. - 2016. - № 6(2). - P. 315-323.

8. Burton, C.H., Turner C. Manure Management: Treatment Strategies for Sustainable Agriculture. $2^{\text {nd }}$ ed. / Silsoe: Silsoe Research Institute, $2003-451 \mathrm{p}$.

9. Georgeson L., Maslin M., Poessinouw M. The global green economy: a review of concepts, definitions, measurement methodologies and their interactions Geo: Geography and Environment. - 2017. - № 4 (1) // Електронний ресурс. - Режим доступу: https://rgs-ibg.onlinelibrary.wiley.com/ doi/pdf/10.1002/geo2.36

10. Global indicator framework adopted by the General Assembly (A/RES/71/313) including annual refinements contained in E/CN.3/2018/2 (Annex II) and E/CN.3/2019/2 (Annex II). - // Електронний ресурс. - Режим доступу:https://unstats.un.org/sdgs/indicators/Global\%20lndicator\%20 Framework\%20after\%202019\%20refinement Eng.pdf

11. Heeres, R.R., Vermeulen, W.J.V., deWalle, F.B Eco-industrial park initiatives in the USA and the Netherlands :first lessons // Journal of Cleaner Production.- 2004. - № 12 (8-10), P. 985-995.

12. Lewandowski, M. Designing the Business Models for Circular Economy // Sustainability. - 2016. - №. 8(1), P. 1-28.

13. Mendes P., Santos A., Nunes L., Teixeira M. Evaluating municipal solid waste management performance in regions with strong seasonal variability // Ecological Indicators. - 2013. - № 30. - P. 170-177.

14. Nilsson-Djerf, J., McDougall, F. Social factors in sustainable waste management // Warmer Bulletin. - 2000. - № 73. - P. 18-20.

15. Sustainable development in the European Union: Monitoring report on progress towards the SDGs in an EU context. 2018 edition - Luxembourg: Publications Office of the European Union, 2018 - 356 p.

16. The Global Waste Management Outlook // Електронний ресурс. Режим доступу: https://www.uncclearn.org/sites/default/files/inventory/ unep23092015.pdf

17. Towards The Circular Economy Vol. 1: An Economic And Business Rationale For An Accelerated Transition. Ellen MacArthur Foundation. 2013. // Електронний ресурс. - Режим доступу: https://www.ellenmacarthurfoundation.org/ assets/downloads/publications/Ellen-MacArthur-Foundation-Towards-theCircular-Economy-vol.1.pdf

18. Tracking progress on Sustainable Development Goals for the regions of Ukraine: choosing indicators and setting baselines. - Kyiv, 2019. 270 P. - // Електронний ресурс. - Режим доступу: http://www.ua.undp.org/ content/ukraine/uk/home/library/sustainable-development-report/trackingprogress-on-SDGs-for-the-regions-of-Ukraine.html?fbclid=IwAR06 0XRAo HKq-u3JNXuyl0ot9sP4roY6OLrFQ2lk6JbvF6w-uh745Z7vXk

19. Waste prevention in Europe - policies, status and trends in reuse in 2017. EEA Report No 4/2018/ - // Електронний ресурс. - Режим доступу: https://www.eea.europa.eu/publications/waste-prevention-in-europe-2017

O. Kononenko, PhD Economy, Associate Professor,

V. Molodyka, MSc

Taras Shevchenko National University of Kyiv, Kyiv, Ukraine

\section{References:}

1. Dovkillia Ukrainy za 2017 rik. Statystychnyi zbirnyk. - K.: Derzhavna sluzhba statystyky Ukrainy, 2018 - 225 s.

2. Mezentsev K.V., Pidhrushnyi H.P., Mezentseva N.I. Rehionalnyi rozvytok v Ukraini: suspilno-prostorova nerivnist i poliaryzatsiia: Monohrafiia. - K.: DP "Print Servis", 2014. - 132 s.

3. Monitorynh ozelenennia ekonomiky pry realizatsii uhody pro asotsiatsiiu Ukraina - YeS. Analitychna dopovid. - // Elektronnyi resurs. Rezhym dostupu: https://www.civic-synergy.org.ua/wp-content/uploads/2018/04/ Monitoryng-ozelenennya-ekonomiky-pry-realizatsiyi-Ugody-pro-asotsiatsiyuUkrayina-YES.pdf

4. Stan sfery povodzhennia $z$ pobutovymy vidkhodamy $\vee$ Ukraini za 2016 ta 2013 roky. Ministerstvo rozvytku hromad ta terytorii Ukrainy // Elektronnyi resurs. - Rezhym dostupu: http://www.minregion.gov.ua/ napryamki-diyalnosti/zhkh/terretory/stan-sferi-povodzhennya-z-pobutovimividhodami-v-ukrayini-za-2016-rik/

5. Stratehiia staloho rozvytku Ukrainy do 2030 roku. Proekt 2017 // Elektronnyi resurs. - Rezhym dostupu: http://www.ua.undp.org/content/ukraine/uk/home/library/sustainable-development-report/SustainableDev-Strategy-for-Ukraine-by-2030.htm

6. Andersen M.S. An introductory note on the environmental economics of the circular economy // Sustainability Science - 2007. - № 2, P. 133-140.

7. Banaitè, D.; Tamošiūnienè, R. Sustainable development: the circular economy indicators' selection model // Journal of Security and Sustainability Issues. - 2016. - № 6(2).- P. 315-323.

8. Burton, C.H., Turner C. Manure Management: Treatment Strategies for Sustainable Agriculture. $2^{\text {nd }}$ ed. / Silsoe: Silsoe Research Institute, $2003-451$ p.

9. Georgeson L., Maslin M., Poessinouw M. The global green economy: a review of concepts, definitions, measurement methodologies and their interactions Geo: Geography and Environment. - 2017. - № 4 (1) // Elektronnyi resurs. - Rezhym dostupu: https://rgs-ibg.onlinelibrary.wiley.com/ doi/pdf/10.1002/geo2.36

10. Global indicator framework adopted by the General Assembly (A/RES/71/313) including annual refinements contained in E/CN.3/2018/2 (Annex II) and E/CN.3/2019/2 (Annex II). - // Elektronnyi resurs. - Rezhym dostupu: https://unstats.un.org/sdgs/indicators/Global\%20Indicator\%20 Framework\%20after\%202019\%20refinement Eng.pdf

11. Heeres, R.R., Vermeulen, W.J.V., deWalle, F.B., 2004. Eco-industrial park initiatives in the USA and the Netherlands :first lessons // Journal of Cleaner Production.- 2004. - № 12 (8-10), P. 985-995

12. Lewandowski, M., 2016. Designing the Business Models for Circular Economy // Sustainability. - 2016. - №. 8(1), P. 1-28

13. Mendes P., Santos A., Nunes L., Teixeira M. Evaluating municipal solid waste management performance in regions with strong seasonal variability // Ecological Indicators. - 2013. - № 30. - P. 170-177.

14. Nilsson-Djerf, J., McDougall, F., 2000. Social factors in sustainable waste management // Warmer Bulletin. - 2000. - № 73. - P. 18-20.

15. Sustainable development in the European Union: Monitoring report on progress towards the SDGs in an EU context. 2018 edition - Luxembourg: Publications Office of the European Union, 2018. - 356 p.

16. The Global Waste Management Outlook // Elektronnyi resurs. Rezhym dostupu: https://www.uncclearn.org/sites/default/files/inventory/ unep23092015.pdf

17. Towards The Circular Economy Vol. 1: An Economic And Business Rationale For An Accelerated Transition. Ellen MacArthur Foundation 2013 // Elektronnyi resurs. - Rezhym dostupu: https://www.ellenmacarthurfoundation.org/ assets/downloads/publications/Ellen-MacArthur-Foundation-Towards-theCircular-Economy-vol.1.pdf

18. Tracking progress on Sustainable Development Goals for the regions of Ukraine: choosing indicators and setting baselines. - Kyiv, 2019. 270 P. - // Elektronnyi resurs. - Rezhym dostupu: http://www.ua.undp.org/ content/ukraine/uk/home/library/sustainable-development-report/trackingprogress-on-SDGs-for-the-regions-of-Ukraine.html?fbclid=IwAR06 0XRAo HKq-u3JNXuyl0ot9sP4roY6OL rFQ2lk6JbvF6w-uh74577vXk

19. Waste prevention in Europe - policies, status and trends in reuse in 2017. EEA Report No 4/2018/ - // Elektronnyi resurs. - Rezhym dostupu: https://www.eea.europa.eu/publications/waste-prevention-in-europe-2017

Надійшла до редколегії 28.11.19

\section{THE TYPIFICATION OF THE REGIONS OF UKRAINE BY POSSIBILITIES FOR SUSTAINABLE WASTE MANAGEMENT}

Sustainable waste management is an urgent task for the modern science and management practice. The search of effective governance mechanisms within the framework of this study was performed in accordance with the concept of sustainable development and circular economy. The transition to a sustainable waste management model is considered as an advancing process to increase the part of mass production and consumption waste which is returned to the manufacturing cycle. In this regard, the assessment of sustainable waste management in the regions should include the dynamics indicators on main components of the waste management. The methodology of this study is based on the generalization of sustainable waste management indicators, which have been analyzed at a certain point in time and in the dynamics as well. The regions of the country were grouped by waste management efficiency. The selected four groups of regions are located rather compact, they have common features in terms of production profile and waste structure. The typification of the regions of Ukraine was developed on the basis of grouping, as well as taking 
into account the specialization of regions in one or a few main industries, levels of urbanization of these regions. Five types of regions were identified: two types with a high share of municipal waste, regions with a predominance of industrial waste, and two types of industrial-agrarian regions where waste of different types is generated with a significant share of agricultural waste. Regions of the same type are typically characterized by the similarity of waste management issues. These can be both traditional problems of accumulating large quantities of waste in landfills, as well as new challenges related to population migration, the formation of new administrative units (united territorial communities), which change the functioning of the current system of waste management. Significant differences in the main waste management indicators for different types require the use of similar (typical) approaches to the development of regional strategies and regional waste management plans.

Keywords: waste, sustainable development, circular economy, waste management efficiency, typification.

Е. Кононенко, канд. экон. наук, доц.,

В. Молодыка, магистр

Киевский национальный университет имени Тараса Шевченко, Киев, Украина

\section{ТИПИЗАЦИЯ РЕГИОНОВ УКРАИНЫ ПО ВОЗМОЖНОСТЯМ УСТОЙЧИВОГО УПРАВЛЕНИЯ ОТХОДАМИ}

Устойчивое управление отходами является актуальной задачей как для современной науки, так и для управленческой практики. Поиск эффективных механизмов управления в рамках данного исследования осуществлен в соответствии с концепцией устойчивого развития и циркулярной экономики. Переход к модели устойчивого управления отходами рассматривается как поступательный проиесс роста доли отходов производства и потребления, которая возвращается в производственный иикл. В связи с этим, оценка устойчивого управления отходов в регионах должна включать индикаторы динамики по основным составляющим управления отходами. Методика данного исследования основывается на нормализации показателей устойчивого управления отходами, которые были проанализированы по состоянию на определенный момент времени, а также в динамике. Было проведено группировку регионов страны по эффективности управления отходами. Выделенные четыре группы регионов имеют четко выраженную территориальную привязку, общие черты производственного профиля и структуры образования отходов. Типизация регионов Украины разработана на основе группировки, а также с учетом специализации регионов в общенациональном разделении труда, уровней урбанизации регионов. Было выделено пять типов регионов: два типа с высокой долей бытовых отходов, регионы с преобладанием промышленных отходов и два типа индустриально-аграрных регионов, имеющих смешанную структуру отходов, с существенной долей отходов сельского хозяйства. Для регионов одного типа, как правило, характерно сходство проблем по обращению с отходами. Это могут быть как традиционные проблемы накопления большого количества отходов в местах их хранения и захоронения, так и новые вызовы, связанные с миграцией населения, образованием новых административных единиц (объединенных территориальных общин), которые вносят изменения в функционирование действующей системы обращения с отходами. Существенные различия по основным показателям обращения с отходами для различных типов требуют использования подобных (типовых) подходов к разработке региональных стратегий и региональных планов управления отходами.

Ключевые слова: отходы, устойчивое развитие, циркулярная экономика, эффективность управления отходами, типизация.

http://doi.org/10.17721/1728-2721.2019.75.6

Удк 911.3

В. Запотоцька, канд. геогр. наук, асист., Л. Риндіч, магістр

Київський національний університет імені Тараса Шевченка, Київ, Україна

\section{ГЕОГРАФІЧНІ ЗАСАДИ ДІЯЛЬНОСТІ КОМПАНІЙ НОВА ПОШТА ТА УКРПОШТА У СФЕРІ ЛОГІСТИЧНОГО СЕРВІСУ НА ПРИКЛАДІ ГОЛОСІЇВСЬКОГО РАЙОНУ МІСТА КИЄВА}

У дослідженні розглянуто теоретичні аспекти логістичної діяльності та логістичного сервісу, з'ясована сутність логістики сервісу та чинники їі формування. Виявлено, що визначальними чинниками розвитку логістичного сервісу $\epsilon$ концентрація населення в межах району, розвинена транспортна інфраструктура, густота шляхів сполучення, а також сформовані економічні зв'язки між учасниками логістичного процесу, що зумовлюють потребу у наданні якісного сервісу. Досліджено особливості діяльності двох великих логістичних компаній - приватної компанії "Нова пошта" та державного підприємства "Укрпошта" в межах Голосіївського району міста Києва. Виявлено, що рівень розвитку компанії прямо залежить від сервісного аспекту їі діяльності, націленості на зручність розташування відділень у пішій доступності користувачів. У роботі окреслені основні напрями роботи логістичних компаній та виконано порівняльний аналіз їх діяльності. Встановлено, що в Голосіївському районі міста Києва кількість відділень "Нова пошта" перевищує більш ніж у 2 рази кількість відділень "Укрпошти". Оцінено показники територіальної концентрації та доступності відділень досліджуваних компаній. Проведене сочіологічне опитування серед населення та гостей Голосіївського району щодо сервісу компаній "Нова Пошта" та "Укрпошта" за основними показниками: рівня довіри, зручності в користуванні, якості обслуговування, вартості послуг та широти спектру надаваних послуг. Аналіз виявив, що до приватної компанії "Нова пошта" населення відчуває більший рівень довіри, ніж до державного підприємства "Укрпошта". Дослідження виявило, що населення більш прихильно відноситься до компанії "Нова пошта" та високо оцінює надаваний нею спектр та якість послуг, зручність розташування відділень. За отриманими результатами, компанія "Нова пошта" займає лідируючі позиції у сфері надання транспортно-складських послуг, що зумовлено направленістю політики підприємства на надання широкого сервісного спектру споживачам та максимальне задоволення їх потреб за оптимальною ціною.

Ключові слова: логістична діяльність, логістичний сервіс, територіальна концентрація, доступність, Голосївський район.

Вступ. Постановка проблеми дослідження. Розвиток логістичної системи виступає одним із пріоритетних напрямків діяльності в господарстві, оскільки забезпечує взаємодію всіх елементів логістичної діяльності, як в організаційному, так і технологічному планах. Розвинена логістична система країни підвищує ії̈ конкурентоспроможність на внутрішньому та міжнародному ринку загальних логістичних та сервісних логістичних послуг. На сучасному етапі розвитку логістики все більша роль відводиться логістичній сервісній діяльності, що виступає однією з базових управлінських технологій. Нинішній ринок логістичних послуг - це ринок покупця, у зв'язку з чим система управління сервісними потоками виступає головним напрямом розвитку логістичних компаній і визначає іiї конкурентоспроможність на міжнародному та внутрішньому рівні. Київ має одну з найрозвиненіших логістичних систем у країні, оскільки є центром поєднання міжнародних та національних транспортних коридорів, а також ядром притягання матеріальних, фінансових, інформаційних потоків. Розвитку логістичної системи у столиці 